\title{
PGAP3 wt Allele
}

National Cancer Institute

\section{Source}

National Cancer Institute. PGAP3 wt Allele. NCI Thesaurus. Code C150292.

Human PGAP3 wild-type allele is located in the vicinity of $17 q 21.2$ and is approximately 26 $\mathrm{kb}$ in length. This allele, which encodes post-GPI attachment to proteins factor 3 protein, plays a role in posttranslational protein modifications. Mutations in this gene are associated with autosomal recessive neurologic hyperphosphatasia with cog nitive disability type 4 (HPMRS4). 